KALAMATIKA Jurnal Pendidikan Matematika

Volume 4, No. 1, April 2019, hal. 37-48

$\mathbf{K} \backslash \mathbf{L} \backslash \mathbf{M} / \mathbf{T} / \mathbf{K} /$

\title{
SPEKTRUM SYMBOL DAN STRUCTURE SENSE MATEMATIKA SISWA MADRASAH TSANAWIYAH
}

\author{
Hamdan Sugilar ${ }^{1}$, Rahayu Kariadinata ${ }^{2}$, Nunung Sobarningsih ${ }^{3}$ \\ ${ }^{1}$ Universitas Islam Negeri Sunan Gunung Djati \\ hamdansugilar@uinsgd.ac.id \\ ${ }^{2}$ Universitas Islam Negeri Sunan Gunung Djati \\ rahayu.kariadinata@uinsgd.ac.id \\ ${ }^{3}$ Universitas Islam Negeri Sunan Gunung Djati \\ nunungsobarningsih@uinsgd.ac.id
}

\begin{abstract}
ABSTRAK
Tujuan penelitian ini adalah untuk mengetahui symbol sense dan structure sense matematika ditinjau dari kemampuan siswa menyelesaikan soal aljabar atau masalah matematika lainnya yang memerlukan ekpresi simbol atau strukturnya. Kesulitan yang dialami siswa dalam menyelesaikan masalah matematika atau aljabar bisa jadi karena kemampuan symbol sense dan structure sense yang rendah atau design didaktik yang disampaikan guru kurang sesuai dengan kategori symbol dan structure sense yang siswa miliki. Seorang siswa dengan symbol dan structure sense yang baik mampu mengapresiasi kekuatan simbol, mengetahui kapan penggunaan simbol-simbol yang tepat dan mampu untuk memanipulasi dan memahami simbol dalam berbagai konteks. Metode yang digunakan pada penelitian menggunakan metode deskriptif kualitatif. Populasi penelitian ini adalah siswa kelas VII Madrasah Tsanawiyah Negeri di Kabupaten Sukabumi dan Kabupaten Bandung, instrumen yang digunakan tes symbol sense dan structure sense, angket, dan form wawancara. Hasil penelitian menunjukkan bahwa kemampuan symbol sense dan structure sense siswa masih rendah hal ini dikarenakan kurangnya pengetahuan konseptual dan manipulasi aljabar, untuk itu perlu adanya model pembelajaran yang tepat untuk meningkatkan kedua kemampuan tersebut.
\end{abstract}

Kata Kunci: Symbol sense, Structure Sense, Aljabar.

\begin{abstract}
The purpose of this study is to determine the symbol sense and structure of mathematical sense in terms of students' ability to solve algebraic problems or other mathematical problems that require symbol expression or structure. Difficulties experienced by students in solving mathematical or algebraic problems may be due to the ability of symbol sense and low structure sense or didactic design that the teacher conveyed is not in accordance with the category of symbols and structure sense that students have. A student with good symbols and structure sense is able to appreciate the power of symbols, knowing when to use the right symbols and being able to manipulate and understand symbols in various contexts. The method used in the study used a qualitative descriptive method. The population of this study was seventh grade students of the Islamic junior high school in Sukabumi and Bandung regencies, the instruments used were symbol and structure sense tests, questionnaires, and interview forms. The results of the study indicate that the ability of symbol sense and student structure
\end{abstract}


sense is still low because of a lack of conceptual knowledge and algebraic manipulation, for this reason it is necessary to have an appropriate learning model to improve both of these abilities.

Keywords: Structure Sense, Symbol Sense, Algebra.

Format Sitasi: Sugilar, H., Kariadinata, R., \& Sobarnigsih, N. (2018). Spektrum Symbol dan Structure Sense Matematika Siswa Madrasah Tsanawiyah. KALAMATIKA Jurnal Pendidikan Matematika, 4(1), $37-48$.

Penyerahan Naskah: 29 September 2018 || Revisi: 12 Maret 2019 || Diterima: 13 Maret 2019

\section{PENDAHULUAN}

Matematika tidak terlepas dari penggunaan simbol-simbol sebagai refresentasi dari hal yang bersifat abstrak. Simbol, gambar dan pola tersebut bukan merupakan gambar material baik konkret atau abstrak dari benda yang bersangkutan, melainkan menyatakan perumpamaan dari elemen, operasi, relasi, dan atau fungsi dalam kerangka ruang dan waktu (Sumarmo, 2010). Matematika dikatakan abstrak karena objek atau simbol-simbol dalam matematika tidak ada dalam kehidupan nyata (Nurhikmayati, 2017). Masalah matematika atau fisika direpresentasikan kebentuk simbol, diagram atau yang lainnya untuk ditemukan penyelesaiannya. Simbol-simbol yang digunakan pada aljabar seperti variabel, koefisien dan konstanta merefresentasikan suatu angka atau bilangan dalam himpunan semesta.

Freudenthal berpendapat bahwa aljabar tidak hanya sebatas pada simbol atau variabel, namun variabel lebih dari sekadar simbol dalam bentuk huruf, Dia menekankan bahwa relasi merupakan salah satu unsur penting dari berpikir aljabar (Wijaya, 2016). Simbol-simbol yang dipelajari dalam aritmatika berbeda dengan simbol yang ada pada aljabar, pada aritmatika siswa harus peka terhadap bilangan atau number sense sedangkan dalam aljabar siswa harus peka terhadap simbol atau symbol sense. Transisi ini yang menyebabkan siswa pada jenjang kelas VII belum terbiasa dengan penggunaan simbol berupa hurup sebagai variabel, konstanta dan yang lainnya yang berimplikasi pada kesulitan dalam menyelesaikan masalah matematika dan fisika dengan baik. Banyak siswa yang tiba di sekolah menengah atas dengan nilai matematika bagus dalam ketika di SMP namun terbukti buruk dalam manipulasi aljabar (Novotná \& Hoch, 2008). Masalah tersebut tentunya tidak boleh berkelanjutan sampai pada tingkat sekolah menengah namun harus ditemukan solusi yang tepat dalam penyelesaian structure sense aljabar, mengingat structure sense merupakan kelanjutan dari pemahaman 
symbol sense dengan memiliki kemampuan structure sense yang baik siswa akan dengan mudah memahami masalah aljabar baik itu masalah kontekstual atau operasi-operasi aljabar. Salah satu penyebab kesulitan siswa dalam memahami aljabar karena siswa kurang memahami, mengerti dan mengoperasikan simbol dan relasi antar simbol.

Untuk mengetahui kesulitan siswa dalam belajar aljabar dapat ditinjau dari pengetahuannya tentang konsep-konsep dan prinsip-prinsip dalam aljabar Tidak sedikit siswa mengalami kesulitan ketika merepresentasikan masalah yang membutuhkan symbol sense atau structure sense seperti pada soal berikut: Sebuah kapal bergerak dari timur ke barat dengan jarak 30 mil, kemudian bergerak ke utara dengan jarak 40 mil. Berapakah jarak tempuh terpendek, kapal bergerak dari timur ke utara? Siswa dengan pemahaman simbol dan structure sense yang rendah sulit dan kebingungan menyelesaikan masalah tersebut. Masalah lainnya siswa lebih mudah mengartikan ' $=$ ' sebagai hasil dari operasi dua bilangan dibandingkan dengan arti ' $=$ ' sebagai ekuivalensi contohnya $12+\ldots=8$ siswa tidak banyak mengalami kesulitan dalam mengisi titik-titik atau jawaban soal tersebut semuanya benar, namun pada soal bentuk $x+8=17$ dengan $x$ anggota bilangan bulat, sebagian siswa mengalami kebingungan dan kesulitan memaknai dan menyelesaikan masalah tersebut. Masalah tersebut harus menjadi perhatian serius mengapa dan faktor apa penyebab siswa mengalalami kesulitan memami symbol dan structure sense, bisa terjadi karena rendahnya pembelajaran baru sampai pada rote learning belum sampai paada meaningful learning (Hapizah, 2018). Kemampuan intuitif terhadap ekspresi simbolik, termasuk keterampilan untuk menafsirkan, untuk memanipulasi, dan untuk memahami simbol dalam peran yang berbeda, dianggap sebagai kunci keberhasilan dalam belajar aljabar (Jupri \& Sispiyati, 2017).

Kepekaan atau penguasaan terhadap simbol akan mempermudah siswa dalam menghadapi masalah yang banyak mengandung simbol-simbol. Seorang siswa dengan symbol sense yang baik mampu mengapresiasi kekuatan simbol, mengetahui kapan penggunaan simbol-simbol yang tepat dan mampu untuk memanipulasi dan memahami simbol dalam berbagai konteks (Samo, 2009). Umumnya pembelajaran matematika, khususnya di SMP, mengenalkan variabel dengan langsung mendefinsikannya sebagai sesuatu yang dilambangkan dengan huruf atau abjad misalnya $x, y$ dan lainnya tanpa melalui konteks yang memaknainya (Dahlan \& Juandi, 2011). Simbol dalam penelitian ini merupakan tanda operasi, lambang untuk mewakili suatu hal yang belum diketahui atau melambangkan angka atau keterangan 
lainnya. Siswa dikatakan dapat menunjukkan kemampuan structure sense aljabar pada sekolah menengah jika mereka dapat mengenali struktur yang sudah dikenal dalam bentuk paling sederhana, menangani istilah majemuk sebagai entitas tunggal dan melalui substitusi yang tepat mengenali struktur yang sudah dikenal dalam struktur yang lebih kompleks dan mampu memilih manipulasi yang tepat untuk memanfaatkan struktur dengan sebaik-baiknya, dapat dikatakan pula bahwa structure sense sebagai kelanjutan dari number sense dan symbol sense (Novotná \& Hoch, 2008).

Symbol sense dan structure sense memiliki peran penting dalam memahami dan memaknai masalah-masalah matematika. Kesulitan yang dialami siswa dalam menyelesaikan masalah matematika atau aljabar bisa jadi karena symbol dan structure sense yang rendah atau design didaktik yang disampaikan guru kurang sesuai dengan kategori symbol sense dan structure sense nya. Pada kajian ini symbol sense diartikan sebagai kepekaan simbol dan structure sense merupakan kepekaan struktur matematika. Kepekaan simbol akan membantu siswa menyelesaikan masalah matematika mengingat matematika banyak memuat simbolsimbol baik secara langsung atau harus mengubah ke bentuk simbol terlebih dahulu. Structure sense dapat membantu siswa memahami dengan baik operasi atau sifat-sifat aljabar. Pada pembelajaran guru diharapkan mampu mengupayakan pembelajaran matematika yang dapat memfasilitasi pengembangan kemampuan berpikir dan pengembangan kemampuan siswa (Nopia Wanti, et all., 2017)

\section{METODE PENELITIAN}

Metode yang digunakan adalah metode penelitian deskriptif, menjelaskan suatu fenomena atau gejala yang bersifat alami dan apa adanya, tidak ada perlakuan yang diberikan atau dikendalikan serta tidak ada uji hipotesis sebagaimana yang terdapat pada penelitian kuantitatif. Tahapan dalam penelitian ini adalah sebagai berikut: (1) uji coba instrumen (2) tes symbol sense dan structure sense, (3) wawancara, dan (4) analisis data.

Jenis data yang digunakan dalam penelitian ini adalah data kualitatif, karena data yang diperoleh nantinya berupa bukan angka tetapi deskripsi dari tingkat kemampuan symbol sense dan structure sense aljabar siswa, berdasarkan indikator dan teori polya. Analisis data yang dilakukan adalah dengan mengevaluasi kemampuan symbol sense dan structure sense aljabar siswa. Data guru dijadikan pedoman pandangan guru terhadap symbol sense dan structure sense terhadap kemampuan siswa. 
Populasi penelitian ini adalah siswa kelas VII Madrasah Tsanawiyah Al Basyariah Kabupaten Bandung dan Madrasah Assasul Islamiyah Kabupaten Sukabumi, aktivitas yang diteliti pada kemampuan siswa memahami symbol dan structure sense mengerjakan soal aljabar memfaktorkan persamaan kuadrat dan mengalikan faktor-faktor persamaan kuadrat. Selanjutnya pengambilan sampel dari populasi dilakukan melalui purposive sampling dipilih dua kelas penelitian, satu kelas VII Madrasah Tsanawiyah Al Basyariah Bandung dan satu kelas VII siswa Madrasah Assasul Islamiyah Sukabumi dimana peneliti melakukan analisa hasil jawaban siswa dan wawancara. Alasan memilih kelas VII dikarenakan pada kelas VII terjadi transisi dari number sense ke symbol sense dan structure sense. Setelah diperoleh satu kelas sebagai sampel penelitian, kemudian siswa dikelompokkan kedalam tiga kelompok yaitu kelompok matematika tinggi, sedang dan rendah berdasarkan nilai yang diperoleh dari guru matematika. Teknik pengumpulan data yang digunakan adalah teknik observasi. observasi ini digunakan untuk mengetahui aktivitas siswa dalam pembelajaran dan selama mengerjakan soal tes. Teknik tes digunakan untuk mengetahui pemahaman symbol sense dan structure sense, teknik angket. Teknik angket digunakan untuk mengetahui sikap siswa memahami symbol sense dan structure sense. Teknik diagnostik, teknik ini dengan memilih tiga siswa dari masing-masing kelompok dengan menggunakan tes diagnostik dan wawancara.

\section{HASIL DAN PEMBAHASAN}

Pemahaman symbol sense siswa diamati melalui tes sebagai berikut umumnya siswa kurang memahami penggunaan simbol dengan tepat. Ketika siswa dihadapi dengan dengan variabel siswa mengalami kesulitan hal ini dikarenakan siswa kebingungan memahami makna simbol berupa variabel misalnya $x, y$, atau $z$. Pemahaman siswa terhadap simbol berupa variabel masih rendah. Kondisi lainnya siswa dengan mudah mengerjakan soal serupa ketika soal tersebut tidak menggunakan simbol-simbol atau variabel. Pada soal nilai $x$ yang memenuhi persamaan $2 x+4=10, x$ anggota bilangan bulat adalah? umumnya siswa kesulitan mengerjakan soal tersebut bahkan ada siswa yang mengasumsikan bahwa $2 x$ ketika nilai $x=3$ disubtitusikan menjadi 23. Tentu hal ini perlu mendapatkan perhatian serius dan sungguhsungguh tentang makna dari $2 x$ dimaknai sebagai $2 x=2 . x$. Masalah tersebut merupakan masalah sederhana bagi sebagian siswa tetapi bisa jadi masalah yang sulit bagi siswa lainnya terdapat $20 \%$ siswa tidak mampu menyelesaikan soal tersebut. Selanjutnya soal tersebut diberikan dalam bentuk soal lain yang ekuivalen yaitu nilai $x$ yang memenuhi persamaan $2 x$ 
$+4=10, x$ anggota bilangan bulat adalah? siswa memahami dengan baik masalah tersebut dan hasil wawancara kepada beberapa siswa diperoleh kesimpulan bahwa lebih mudah ditulis kedalam bentuk titik-titik dari pada menggunakan simbol berupa $x$. Penyelesaian dari soal tersebut sebagian siswa ada yang memaknai dengan pemahaman bahwa 6 merupakan solusi untuk $2 x$ karena $6+4=10$. Selanjutnya $2 x=6$, nilai $x=3$ siswa lebih memahami dan dapat menyelesaikan soal tersebut dengan baik.

Masalah aljabar banyak melibatkan simbol atau variabel yang menjadi dasar dalam menyelesaikan masalah matematika karena matematika dipandang sebagai bahasa simbol. Simbol atau variabel dalam aljabar dipandang sebagai tools dalam menyelesaikan masalah matematika tanpa simbol rasanya sulit untuk diselesaikan. Misalnya pada masalah sehari-hari pada soal penelitian bagian III nomor 1: jumlah siswa kelas VII 50 siswa. Jika siswa laki-laki 10 lebih banyak dengan siswa perempuan, maka berapa jumlah siswa perempuan? Untuk memudahkan penyelesaian masalah tersebut tentunya diselesaikan dengan pendekatan aljabar.

Instrumen terdiri dari angket dan soal simbol dan struktur sense. Soal yang diberikan kepada siswa terdiri dari tiga bagian, bagian pertama pilihan ganda, bagian dua tipe benar salah dan bagian ke tiga uraian singkat. Adapun hasil tes terlihat sebagaimana Tabel 1.

Tabel 1. Kemampuan Simbol Sense Matematika

\begin{tabular}{|c|c|c|}
\hline Tipe Soal & Soal & Rata-rata \\
\hline \multirow{2}{*}{$\begin{array}{l}\text { Pilihan } \\
\text { Ganda }\end{array}$} & $\begin{array}{l}\text { 1. Nilai } x \text { yang memenuhi persamaan } 2 x+4=10, x \in \mathbb{Z} \text { (bulat) adalah... } \\
\begin{array}{llll}\text { a. } 4 & \text { b. } 3 & \text { c. } 2 & \text { d. } 1\end{array}\end{array}$ & 59,38 \\
\hline & $\begin{array}{l}\text { 2. Nilai } x \text { yang memenuhi persamaan } 7-(-2)=x+4, x \in \mathbb{Z} \text { (bulat) adalah... } \\
\begin{array}{llll}\text { a. } 7 \text { b. } 6 & \text { c. } 5 & \text { d. } 4\end{array}\end{array}$ & 57,81 \\
\hline \multirow{3}{*}{ Benar Salah } & 1. NIlai ${ }^{x}$ yang memenuhi persamaan $x+4=2 x-6, x \in \mathbb{Z}$ (bulat) adalah 10 & 37,50 \\
\hline & 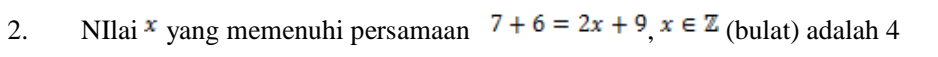 & 51,56 \\
\hline & $\begin{array}{l}\text { 1. Jumlah siswa kelas VII } 50 \text { siswa. Jika siswa laki-laki } 10 \text { lebih banyak } \\
\text { dengan siswa perempuan, maka berapa jumlah siswa perempuan? }\end{array}$ & 48,40 \\
\hline \multirow[t]{2}{*}{ Uraian } & $\begin{array}{l}\text { Sebutkan ukuran yang mungkin dari persegi panjang dengan luas } 36 \mathrm{~cm}^{2} \\
\ldots\end{array}$ & 45,31 \\
\hline & $\begin{array}{l}\text { 5. Gunakan tiga angka dan dua operasi bilangan yang berbeda dari angka } \\
1,2,3,4,5,6,7,8 \text {, dan } 9 \text { yang hasilnya operasinya } 10 \text {. }\end{array}$ & 51,56 \\
\hline
\end{tabular}

Bentuk soal yang diberikan kepada siswa memiliki tiga tipe terdiri dari soal pilihan ganda, benar-salah dan isian singkat. Maksud dari tiga tipe yang diberikan agar dapat diketahui tipe soal mana yang mampu menunjukkan kemampuan simbol dan stuktur sense matematikanya.

Pada bahasan terhadap kemampuan kepekaan simbol siswa madrasah tsanawiyah dibahas beberapa temuan terkait dengan kemampuan siswa memahami symbol sense 
matematika. Pada soal nomor 1 diperoleh rata-rata 59,38 dengan simpangan baku 0,49 hal ini tergolong pada kategori rendah. Umumnya siswa telah memahami maksud soal dengan baik namun kurang mampu menyelesaikan operasi dan memahami makna simbol $x$ sehingga kemampuan simbol sense bentuk simbol peubah dengan indikator mengidentifikasi makna dari simbol siswa dalam kategori rendah. Siswa lebih mudah mengerjakan soal dalam bentuk titik-titik daripada dengan simbol. Pada soal nomor 2 diperoleh rata-rata 57, 81 dengan simpangan baku 0,49 hal ini tergolong pada kategori rendah. Pada soal tersebut siswa harus mengenal simbol-simbol operasi bilangan bulat, dimana bentuk perkalian negatif dengan negatif hasilnya positif. Siswa kurang mampu menyelesaikan operasi dan memahami makna simbol $x$ sehingga kemampuan simbol sense dengan indikator mengidentifikasi makna dari simbol siswa dalam kategori rendah.

Pada soal nomor 1 bentuk benar salah diperoleh rata-rata 37,50 dengan simpangan baku 0,97 hal ini tergolong pada kategori rendah. Umumnya kurang memahami makna simbol $x$ dan menyelesaikan persamaan tersebut hal ini disebabkan kemampuan aritmatika aljabar siswa masih rendah operasi aljabarnya perlu ditingkatkan. Indikator menjelaskan hubungan antar simbol yang digunakan dalam memecahkan masalah dalam kategori rendah. Pada soal nomor 1 bentuk uraian diperoleh rata-rata 48,43 dengan simpangan baku 1,06 hal ini tergolong pada kategori rendah. Umumnya siswa kurang mampu mengubah soal cerita ke bentuk simbol matematika. Siswa kebingungan menyelesaikan masalah tersebu dikarenakan tidak memahami makna soal dan harus bagaimana memulai menyelesaikannya, serta simbolsimbol apa saja yang digunakan untuk mengubah soal cerita ke bentuk simbol masih kurang memahami dengan baik. Indikator menjelaskan mengaitkan simbol dengan masalah dalam kategori rendah.

Soal nomor 5 bentuk uraian diperoleh rata-rata 45,31 dengan simpangan baku 1,18 hal ini tergolong pada kategori rendah. Umumnya siswa keliru dalam memahami soal dan kurang hati-hati dalam memahami soal sehingga sebagian jawaban siswa belum mengarah pada jawaban yang tepat. Padahal konteks soal ini sederhana apabila siswa memahami simbol operasi bilangan yang berbeda dan bilangan-bilangan yang berbeda ia akan dengan mudah menyebutkan jawaban dengan tepat. Siswa hanya menyelesaikan satu operasi $9+1=10$ seharusnya tiga angka dan dua operasi bilangan yang berbeda misalnya $9+2-1=10$ 
Indikator menyebutkan simbol-simbol yang dapat digunakan dalam pemecahan masalah dalam kategori rendah.

Dari beberapa bahasan tentang kemampuan symbol sense matematika siswa umumnya berada dalam kategori rendah hal ini harus mendapatkan perhatian serius perlu ada treatment melalui model atau strategi pembelajaran yang tepat agar siswa peka terhadap simbol-simbol matematika dikarenakan matematika tidak akan pernah lepas dari penggunaan simbol-simbol baik itu bilangan atau operasi bilangan. Hal ini dikarenakan simbol merasa bingung atau kurang menyenangi simbol aljabar berupa peubah atau variabel $x, y$ atau $z$ mereka bingung apa makna dari simbol tersebut. Para siswa memiliki banyak kesalahpahaman dalam penggunaan simbol-simbol dalam Aljabar yang memiliki kaitan dengan pembelajaran Aljabar. Tampaknya masalah yang dihadapi oleh siswa memiliki kaitan dengan kurangnya pengetahuan konseptual, kesulitan siswa dalam mengubah kalimat atau pernyataan ke dalam bentuk aljabar dan simbolik (Samo, 2009).

Tabel 2. Kemampuan Struktur Sense

\begin{tabular}{|c|c|c|}
\hline Tipe Soal & Soal & Rata-rata \\
\hline \multirow{5}{*}{ Pilihan Ganda } & 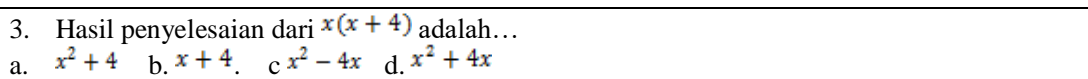 & 60.94 \\
\hline & 4. Hasil penyelesaian dari $(x-3)(x+4)$ adalah... & 50,00 \\
\hline & a. $x^{2}-3 x-12 \quad$ b. $x^{2}+x+12$ & \\
\hline & c. $x^{2}+x-12 \quad$ d. $x^{2}-x+12$ & \\
\hline & 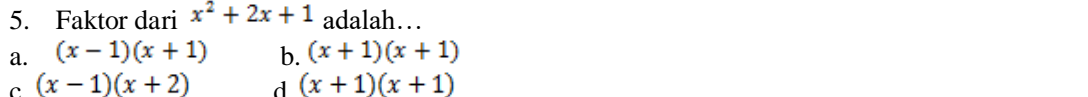 & 39,06 \\
\hline \multirow{3}{*}{ Benar-Salah } & 3. Hasil penyelesaian dari $(2 x+3)(x+4)$ adalah $2 x^{2}+8 x+12$ & 51,56 \\
\hline & 4. Faktor dari $x^{2}-y^{2}$ adalah $(x+y)(x-y)$ & 43,75 \\
\hline & 5. Hasil penyelesaian dari ${ }^{x(x-2)(x+2)}$ adalah... & 54,68 \\
\hline \multirow[b]{2}{*}{ Uraian } & $\begin{array}{l}\text { 2. Umur Ani di tambah umur Mirna } 51 \text { tahun. Jika umur Ani adalah setengah umur Mirna. } \\
\text { Berapa umur Ani? bagaimana cara kamu menyelesaikan soal tersebut? }\end{array}$ & 46,35 \\
\hline & 4. Faktor dari $2 x^{2}+10 x+12$ adalah... & 41,15 \\
\hline
\end{tabular}

Pada bahasan terhadap kemampuan kepekaan struktur siswa madrasah tsanawiyah dibahas beberapa temuan terkait dengan kemampuan siswa memahami structure sense/ kepekaan struktur matematika. Berdasarkan Tabel 2 terlihat bahwa, pada soal nomor 3 bentuk soal pilihan ganda diperoleh rata-rata 60,94 dengan simpangan baku 0,49 hal ini tergolong pada kategori sedang. Siswa dapat memahami struktur perkalian simbol dengan simbol sehingga kepekaan siswa terhadap struktur operasi perkalian dua faktor aljabar. Pada soal nomor 5 bentuk soal pilihan ganda diperoleh rata-rata 39,06 dengan simpangan baku 0,49 hal ini tergolong pada kategori sangat rendah. Umumnya siswa tidak dapat menyelesaikan soal 
pemfaktoran karena bingung dan merasa kesusahan bagaimana langkah menyelesaikannya kepekaan struktur dalam pemfaktoran masih lemah, perlu ada model pembelajaran yang tepat agar siswa berhasil menyelesaikan soal pemfaktoran atau masalah lainnya tentang alajabr. Kemampuan structure sense, kemampuan intuitif terhadap, ekspresi simbolik, termasuk keterampilan untuk menafsirkan, memanipulasi, mengelola, dan melakukan simbol dalam peran yang berbeda, dianggap sebagai kunci keberhasilan dalam mempelajari aljabar (Jupri \& Sispiyati, 2017).

Pada soal nomor 2 bentuk soal uraian diperoleh rata-rata 46,35 dengan simpangan baku 1,25 hal ini tergolong pada kategori rendah. Umumnya siswa tidak dapat menyelesaikan soal disebabkan kesulitan dalam mengubah atau memanipulasi soal cerita ke bentuk simbol. Pada soal ini siswa harus memiliki kepekaan struktur kalimat dan strukur kerkaitan antara yang diketahui dengan yang ditanyakan.

Tabel 3. Sikap Siswa terhadap Symbol sense dan Structure Sense

\begin{tabular}{|c|c|c|c|c|c|}
\hline \multirow[t]{2}{*}{ No. } & \multirow[t]{2}{*}{ Penyataan } & \multicolumn{4}{|c|}{ Kategori $(\%)$} \\
\hline & & S & S & S & TS \\
\hline 1. & Matematika salah satu pelajaran favourit saya & 12.50 & 36.11 & 43.06 & 8.33 \\
\hline & $\begin{array}{l}\text { Hanya materi tertentu saja yang membuat saya menyukai pelajaran } \\
\text { matematika }\end{array}$ & 16.67 & 40.28 & 31.94 & 11.11 \\
\hline 3. & Guru menggunakan media dalam menjelaskan matematika & 11.11 & 51.39 & 27.78 & 9.72 \\
\hline 4. & Saya kurang memahami simbol matematika & 12.50 & 58.33 & 23.61 & 5.56 \\
\hline & $\begin{array}{l}\text { Saya paling tidak suka matematika apabila memuat variabel misalnya } \\
\text { x,y,dan z }\end{array}$ & 9.72 & 40.28 & 43.06 & 6.94 \\
\hline & $\begin{array}{l}\text { Pemahaman tentang operasi-operasi pada aljabar dan pemfaktoran saya } \\
\text { masih kurang }\end{array}$ & 25.00 & 44.44 & 20.83 & 9.72 \\
\hline & $\begin{array}{l}\text { Soal } x+2=5 \text {, lebih sulit dibanding dengan } \ldots+2=5 \text {, berapa bilangan } \\
\text { yan tepat untuk mengisi titik-titik sehingga pernyataan tersebut bernilai } \\
\text { benar }\end{array}$ & 33.33 & 43.06 & 20.83 & 2.78 \\
\hline & $\begin{array}{l}\text { Saya merasa kesulitan apabila soal matematika diubah kedalam bentuk } \\
\text { soal cerita }\end{array}$ & 19.44 & 44.44 & 25.00 & 11.11 \\
\hline & $\begin{array}{l}\text { Saya merasa kesulitan dalam menyelesaikan soal berikut } \\
x(x+2)(x-3)\end{array}$ & 29.17 & 45.83 & 22.22 & 2.78 \\
\hline 10. & Saya paling suka apabila guru menyampaikan materi sampai tuntas & 44.44 & 38.89 & 11.11 & 5.56 \\
\hline
\end{tabular}

Tabel 3 membahas tentang bagaimana respon siswa terhadap kepekaan simbol dan struktur. Pernyataan dikategorikan positif untuk siswa yang memberikan jawaban sangat setuju dan setuju untuk pernyataan positif dan negatif untuk pernyataan negatif atau sebaliknya. Hanya beberapa pernyataan yang akan dibahas pernyataan nomor 4. Sebanyak 70, $83 \%$ siswa tidak memahami simbol dan makna peubah atau variabel karena pada siswa kelas VII terjadi masa transisi penggunaan variabel akibatnya kepekaan simbol siswa menjadi rendah. Pernyataan nomor 5 sebanyak $50 \%$ siswa tidak menyenangi penggunaan simbol 
$x, y$, dan $z$ dalam menyelesaikan soal matematika umumnya ketika ada simbol tersebut tidak memahami makna dari simbol itu. Pernyataan nomor 7 sebanyak 76,36\% siswa menyatakan bahwa soal $\mathrm{x}+2=5$, lebih sulit dibanding dengan $\ldots .+2=5$, berapa bilangan yan tepat untuk mengisi titik-titik sehingga pernyataan tersebut bernilai benar. 63,88 \% mengalami kesulitan apabila menyelesaikan soal cerita hal ini disebabkan siswa kurang memahami soal dan menngubah kalimat ke bahasa simbol matematika, disamping kepekaan struktur yang lemah. Bingung simbol yang digunakan dan struktur keterkaitan antar kalimat yang diubah ke bentuk simbol.

\section{KESIMPULAN}

Berdasarkan hasil penelitian ini dapat disimpulkan bahwa kemampuan symbol sense dan structure sense siswa masih rendah hal ini dikarenakan kepekaan simbol dan manipulasi aljabar masih rendah. Faktor penyebabnya antara lain: siswa kesulitan mengubah soal cerita ke bentuk simbol, kurang memahami makna simbol atau peubah itu apa, dan kebingungan mengoperasikan simbol itu. Siswa lebih meyenangi penggunaan titik-titik pada soal yang ditanyakan daripada penggunaan simbol atau peubah pada aljabar. Kemampuan symbol sense, yang baik dapat menggunakan simbol dengan benar; memahami sifat simbol dalam situasi yang berbeda, seperti, dalam fungsi, dalam variabel dan dalam hubungan antara representasi aljabar. Karena symbol sense siswa rendah berdampak pada rendahnya structure sense siswa. Hal ini disebabkan karena structure sense merupakan operasi dari simbol-simbol yang kemampuannya lebih tinggi daripada symbol sense.

\section{REKOMENDASI}

Berdasarkan hasil penelitian yang telah dilakukan kemampuan symbol dan structure sense siswa masih rendah. Untuk itu perlu ada metode yang tepat untuk meningkatkan kemampuan tersebut mengingat kemampuan tersebut berdampak pada kemampuan siswa menyelesaikan soal aljabar atau problem solving.

\section{UCAPAN TERIMAKASIH}

Penulis ucapkan terima kasih kepada Lembaga Penelitian dan Pengabdian Kepada Masyarakat (LP2M) UIN Sunan Gunung Djati Bandung yang telah memberikan bantuan 
penelitian Litapdimas BOPTN 2018. Penelitian ini merupakan penelitian yang didanai dari anggaran penelitian BOPTN 2018.

\section{REFERENSI}

Samo, M. A. (2009). Students' Perceptions about the Symbols, Letters and Signs in Algebra and How Do These Affect Their Learning of Algebra: A Case Study in a Government Girls Secondary School Karachi. International Journal for Mathematics Teaching and Learning.

Dahlan, J. A., \& Juandi, D. (2011). Analisis Representasi Matematik Ssiswa Sekolah Dasar dalam Penyelesaian Masalah Matematika Kontekstual. Jurnal Pengajaran Matematika dan Ilmu Pengetahuan Alam, 16(1), 128.

Hapizah \& Mulyono, B. (2018). Pemahaman Konsep dalam Matematika. KALAMATIKA Jurnal Pendidikan Matematika, 3(2), 103-122.

Jupri, A., \& Sispiyati, R. (2017). Expert Strategies in Solving Algebraic Structure Sense Problem: The Case of Quadratic Equations. Journal of Physics: Conference Series, 812.

Nopia, W., et all. (2017). Pembelajaran Induktif pada Kemampuan Penalaran Matematis dan Self-Regulated Learning Siswa. Jurnal Analisa, 3(1), 56-69.

Novatna, J., \& Hoch, M. (2008). How Structure Sense for Algebraic Expressions or Equations is Related to Structure Sense for Abstract Algebra. Mathematics Education Research Journal, 20(2), 93-104

Nurhikmayati, I. (2017). Kesulitan Siswa Berpikir Abstrak Matematika dalam Pembelajaran Problem Posing Berkelompok. KALAMATIKA Jurnal Pendidikan Matematika, 2(2), 159-176.

Sumarmo, U. (2010). Berpikir dan Disposisi Matematik: Apa, Mengapa dan Bagaimana Dikembangkan pada Peserta Didik. Artikel pada FPMIPA UPI Bandung. 
Wijaya, A. (2016). Aljabar : Tantangan Bbeserta Pembelajarannya. Jurnal Gantang, 1(1), 115. 